Relations industrielles

Industrial Relations

\title{
Relative Wage Differentials in Canadian Industries, by Pradeep Kumar, Kingston, Industrial Relations Centre, Queen's University, 83 p.
}

\section{Paul Phillips}

Volume 30, numéro 4, 1975

URI : https://id.erudit.org/iderudit/028676ar

DOI : https://doi.org/10.7202/028676ar

Aller au sommaire du numéro

\section{Éditeur(s)}

Département des relations industrielles de l'Université Laval

\section{ISSN}

0034-379X (imprimé)

1703-8138 (numérique)

Découvrir la revue

Citer ce compte rendu

Phillips, P. (1975). Compte rendu de [Relative Wage Differentials in Canadian Industries, by Pradeep Kumar, Kingston, Industrial Relations Centre, Queen's University, 83 p.] Relations industrielles / Industrial Relations, 30(4), 808-809. https://doi.org/10.7202/028676ar

Tous droits réservés (C) Département des relations industrielles de l'Université Laval, 1975
Ce document est protégé par la loi sur le droit d'auteur. L'utilisation des services d'Érudit (y compris la reproduction) est assujettie à sa politique d'utilisation que vous pouvez consulter en ligne.

https://apropos.erudit.org/fr/usagers/politique-dutilisation/ 
beaucoup plus loin, ce que Holland et Skolnik en font pas.

Dans le chapitre suivant, les auteurs veulent d'abord présenter sommairement l'évolution de la politique de maind'oeuvre au Canada. En fait, ce chapitre donne plus l'historique des programmes de main-d'oeuvre que l'historique de la politique elle-même. En fait, les auteurs ne font presqu'aucune référence à celle-ci.

Le reste du livre est consacré à l'examen de particularités du contexte ontarien quant à l'application d'une politique de main-d'oeuvre. Après avoir comparé beaucoup trop brièvement (et même trop superficiellement par rapport au Québec) l'Ontario et l'expérience de d'autres juridictions en ce qui a trait à la main-d'oeuvre, les auteurs examinent la façon de tenir compte des activités de main-d'oeuvre dans les comptes publics et font quelques suggestions quant à la politique de main-d'oeuvre en Ontario.

Malgré les critiques soulevées, cet ouvrage a au moins le mérite de représenter un effort d'opérationnalisation d'une politique de main-d'oeuvre propre à une région donnée. Cela s'inscrit à l'intérieur de la récente tendance vers la provincialisation de la politique de maind'oeuvre au Canada. Malgré l'existence de deux livres blancs non-publiés sur le sujet au Québec, il est à se demander si la Belle Province en arrivera à faire un exercice encore plus systématique et plus imaginatif que celui de l'Ontario.

\section{Jean SEXTON}

\section{Université Laval}

\section{Relative Wage Differentials in Canadian}

Industries by Pradeep Kumar, Kingston, Industrial Relations Centre, Queen's University, $83 \mathrm{p}$.

Relative Wage Differentials in Canadian Industries is a new and welcome addition to the empirical literature testing a number of the theories relating to the determination of wage differentials in the contemporary labour market. Specifically Kumar attempts «to reconcile the competitive neoclassic theory of the labour market... with the institutional model...» (p. viii) His concensus model accepts the basic competitive market determination of wage differentials sub- ject to modification by institutional forces and to the non-pecuniary aspects of specific employment as discussed by Adam Smith.

The formal model includes institutional variables for unionization and for the structure of the product market, variables for non-pecuniary attributes of employment including irregularity of employment, intensity of physical effort, frequency of industrial accidents and regional location mix. The equation was estimated for two occupational groups, unskilled labour (labourers) and skilled labour (maintenance mechanics) employed in 26 manufacturing industries from wage data in the Department of Labour.

\section{Wages Rates, Salaries and Hours of Labour}

Kumar, in discussing the rationale for testing both skilled and unskillec classifications bases it on the hypothesis that the skilled labour market more closely approximates the competitive model (or, one might suggest, the human capital model) while the unskilled labour market is more highly influenced by institutional variables. This difference, which he calls the «skilled worker hypothesis », is also predicted by the "dual labour market " model although nowhere does he discuss the dual model as a possible explanation of his empirical results.

The first part of the study analyzes the behaviour of interindustry wage differentials over the period 1952 to 1970 . Kumar concludes that the persistence of relative wage differentials almost unchanged over the period means that the competitive market model is not a sufficient explanation of wage determination, at least in manufacturing, and justifies inclusion of non-pecuniary and institutional variables in the wage determination equation. The high positive correlation between the relative levels of unskilled wages and skilled wages by industry suggest to Kumar that differentials are primarily associated with industry characteristics.

The model proposed for texting hy pothesizes that the basic competitive market wage will be enhanced by nonpecuniary aspects of industry employment; irregularity of work due to seasonal and cyclical variability, arduous- 
ness of work (the percentage of females in employment being used as a proxy), and physical hardship as estimated by the frequency of industrial accidents. An industry location mix variable was included on the grounds that certain regions in Canada persistently pay higher wages in most industries. The model also hypothesizes that skilled wages will be increased by concentration in the product market because large firms will pay a premium to skilled workers for greater hiring selectivity and employment stability due to higher hiring and training costs for skilled workers in large as opposed to small firms; and that unskilled wages will be increased by the degree of unionization and concentration since unions by insisting on «equitable » treatment for unskilled workers are able to reduce the relative wage differentials between skilled and unskilled.

The empirical results are in large measure consistent with the hypotheses. The equations explain between 60 and 75 percent of the differentials. However, it should be noted that both irregularity of employment variables and the location mix variable were not significant. On the latter point there is some indication that locational differentials are decreased by high levels of industry unionization. Furthermore, the physical hardship variable, while significant, had the opposite effect to that expected. That is, the higher the level of industrial accidents, the lower was the pay. To confuse the issue, however, in those industries with high accident rates the lower was the unskilled-skilled differential.
The most significant of the non-pecuniary variable was the arduousness of work variable. I am uneasy, however, with the selection of the percentage of females as the relevant proxy. Alternatively, one could suggest that the participation of females in an industry is a result of low wages; or that it reflects social attitudes (possibly historically determined) resulting in looser labour market supply conditions with a resulting depressing effect on industry wages.

The institutional variables behaved as expected. According to Kumar's results, completely oligopolistic industries pay 30 percent higher wages to skilled mechanics than do competitive industries, independent of unionism. Unskilled workers, however, benefit significantly only if both concentration and unionization are present, up to 40 percent premium for completely unionized, completely oligopolistic industries.

The results of this study are interesting but as Kumar himself points out, they do not tell us much about the internal dynamics of wage making. Why, for instance, does the large firm require greater employment stability from skilled workers? Why does the physical hardship of industry employment have a perverse effect on wages. It may be suggested that some of the hypotheses of the dual labour market may provide one potentially fruitful avenue for further search along the road to a general understanding of how the labour market works.

Paul PHILLIPS

University of Manitoba 